\title{
Оптимізація параметрів робочих органів машин для вирощування та збирання цукрових буряків
}

\author{
В.Л. Курило ${ }^{1}$, В.М. Пришляк ${ }^{2}$ \\ Вінницький національний аграрний університет (м. Вінниця, Україна) \\ email: ${ }^{1}$ kurilo_v@ukr.net, ${ }^{2}$ viktor.prishlyak@i.ua
}

\begin{abstract}
У статті викладено удосконалені агротехнічні заходи вирощування та збирання цукрових буряків, що забезпечують підвищення якості передпосівного обробітку ґрунту, сівби насіння, ефективності дії мінеральних добрив та гербіцидів і, в зв'язку з цим, створення більш сприятливих агрофізичних умов для росту і розвитку рослин, підвищення врожайності цукрових буряків та зменшення витрат на виробництво.

Представлено розроблені технологічні процеси та оптимізовані параметри робочих органів машин для вирощування і збирання цукрових буряків: проведення локального внесення мінеральних добрив, передпосівного обробітку ґрунту та сівби насіння одним агрегатом за один його прохід, боротьбу з бур'янами шляхом обприскування посівів гербіцидами у фазі формування рослинами бур'янів сім'ядоль, пошарового розпушування ґрунту в міжряддях до змикання листя в суміжних рядках, створення необхідних умов для росту і розвитку цукрових буряків та забезпечення елементами живлення рослин протягом періоду вегетації під час найбільшої їх потреби, догляду за рослинами цукрових буряків на важких за механічним складом ґрунтах та після випадання значної кількості опадів і підвищення щільності ґрунту, міжрядного обробітку ґрунту з підгортанням рослин у рядках, збирання буряків з підкопуванням коренеплодів для умов підвищеної щільності і низької вологості. Доцільність інноваційних розробок підтверджена проведеними експериментальними дослідженнями у польових умовах.

Результати досліджень можуть бути використані для удосконалення та оптимізації зональних технологій і технічних засобів для вирощування і збирання цукрових буряків, а також у навчальному процесі під час підготовки майбутніх агроінженерів до інноваційної проектної діяльності.
\end{abstract}

Ключові слова: оптимізація, параметри, робочі органи, машина, вирощування, збирання, иукрові буряки.

Постановка проблеми. Цукрові буряки є основною цукроносною сільськогосподарською культурою в Україні. Існуючі технології й сучасні технічні засоби, що застосовуються для вирощування та збирання цукрових буряків, не забезпечують необхідної якості виконання технологічних процесів. Зростаючі вимоги обумовлюють необхідність постійного вдосконалення існуючих і створення нових високопродуктивних машин і машинних агрегатів для забезпечення якісного виконання технологічних процесів у буряківництві. Високі норми висіву насіння, зрідженість та забур'яненість посівів, неефективне використання добрив, втрати при збиранні зумовлюють зниження врожайності коренеплодів цукрових буряків, що призводить до значних витрат коштів на їх виробництво. У зв'язку з цим розробка нових і удосконалення існуючих технологічних процесів вирощування та збирання цукрових буряків $\epsilon$ актуальною проблемою, що має важливе наукове і практичне значення.

Аналіз останніх досліджень. Передумовою проведення теоретичних і експериментальних наукових досліджень було всебічне вивчення літературних джерел та патентів.
Вивчались фундаментальні роботи 3 теорії і розрахунку технічних засобів механізації для буряківництва. Зокрема, великий науковий і практичний інтерес представляють наукові здобутки відомого вченого акад. П.М. Василенка. У монографії [1] зазначено, що Василенко П.М. був безпосереднім керівником і виконавцем цілої низки розробок із створення конструкцій сівалок, технічних засобів для внесення добрив, культиваторів для суцільного та міжрядного обробітку ґрунту, бурякозбиральних машин з обрізанням гички на корені та ін.

Для теоретичного обґрунтування, розрахунку параметрів і проектування технічних засобів механізації для буряківництва використовувалась книга [2], у котрій на високому науковому рівні розглянуто задачі з основ теорії руху частинки чи тіла по фррикційним поверхням, які можуть бути поверхнями робочих або транспортуючих органів сільськогосподарських машин (ґрунтообробних, посівних, збиральних чи ін.).

На різних етапах розвитку сільськогосподарської техніки з'являлись автоматичні пристрої, що відповідали заданим вимогам. Академіком П.М. Василенком у співавторстві з канд. техн. 
наук И.И. Василенком узагальнено матеріали 3 автоматизації сільськогосподарського виробництва [3]. У книзі [3] викладено елементи теорії лінійних систем автоматичного регулювання та розглянуто конструкції основних автоматичних пристроїв, призначених для автоматизації процесів сільськогосподарського виробництва, що, безумовно, доцільно використовувати при проектування машин і знарядь для буряківництва.

Зростаючі вимоги до конструкцій машин, конкурентоздатних на ринку сільськогосподарського машинобудування за оптимальними якісними, енергетичними, економічними та екологічними характеристиками обумовлюють необхідність постійного вдосконалення існуючих і створення принципово нових високопродуктивних машин і машинних агрегатів для забезпечення виконання технологічних процесів у буряківництві. Застосування теоретичних методів проектування та дослідження особливостей фрункціонування машин, розроблених П.М. Василенко і В.П. Василенко [4] дозволяють розв'язувати задачі аналізу та синтезу конструктивно складних машин для вирощування та збирання цукрових буряків.

У монографії [5] викладено основоположні механіко-математичні передумови, що необхідні для вирішення задач аналізу і синтезу параметрів технологічних процесів, які виконуються при вільному та невільному русі частинок і твердих частин сільськогосподарських матеріалів під дією робочих органів машин.

У довіднику з механізації виробництва цукрових буряків [6], котрий підготовили автори О.О. Проценко, В.І. Паламарчук, А.М. Козачук, В.С. Глуховский, С.А. Забаштанський, М.М. Зуєв, А.М. Мазуренко, П.В. Савич, В.І. Пиркін, В.Б. Миронов викладено прогресивні технології вирощування високих урожаїв цукрових буряків 3 мінімальними затратами ручної праці. Вченими даються рекомендації з формування раціонального комплексу машин і підготовки їх до набору та застосування в залежності від виробничих умов бурякосіючих господарств.

Проводився аналітичний огляд і інших літературних джерел, наприклад, [7, 8, 13, 14] і патентний пошук результати котрих показали, що бурякозбиральні технічні засоби не забезпечують необхідної якості вирощування та збирання цукрових буряків, що є підставою для приводом для проведення науково-практичних досліджень із зазначених проблемних питань.

Мета досліджень. Удосконалити технологічні процеси вирощування та збирання цукрових буряків і розробити технічні засоби механізації $з$ оптимальними параметрами, здатними забезпечити ведення буряківництва у конкурентному ринковому середовищі.

Результати досліджень. Для підвищення якості передпосівного обробітку ґрунту, сівби насіння, ефективності дії мінеральних добрив та гербіцидів і, в зв'язку з цим, створення більш сприятливих агрофізичних умов для розвитку рослин, підвищення врожайності цукрових буряків та зменшення витрат на виробництво вдосконалено спосіб вирощування цукрових буряків [9]. При застосуванні удосконаленого способу вирощування цукрових буряків локальне внесення мінеральних добрив, передпосівний обробіток ґрунту та сівбу насіння проводять одним агрегатом за один його прохід (рис. 1).

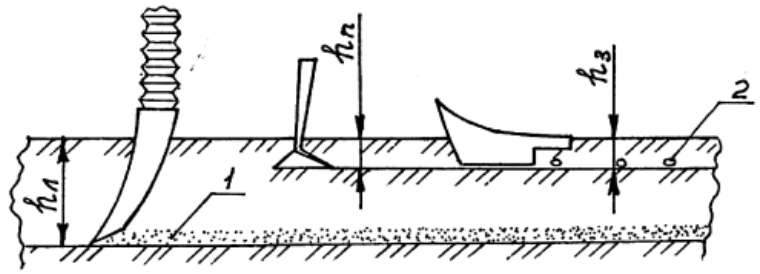

Рис. 1. Схема локального внесення мінеральних добрив, передпосівного обробітку ґрунту

та сівби насіння за один прохід агрегату:

$h_{л}$ - глибина локального внесення мінеральних добрив (1); $h_{\text {п }}$ - глибина передпосівного

обробітку ґрунту; $h_{3}$ - глибина загортання насіння (2)

При цьому локальне внесення мінеральних добрив здійснюють на глибину $h_{\text {л }}=12 \ldots 20 \mathrm{~cm}$, яка перевищує глибину загортання насіння $h_{3}=3 \ldots 4 \mathrm{~cm}$ у $4 \ldots 5$ разів, за співвідношенням $h_{\text {л }}=(4 \ldots 5) h_{3}$. Передпосівний обробіток ґрунту $\left(h_{\Pi}, \mathrm{cm}\right)$ проводять на глибину загортання насіння, тобто $h_{\text {п }}=h_{3}=3 \ldots 4 \mathrm{~cm}$.

За локального внесення мінеральних добрив одночасно з передпосівним обробітком ґрунту та сівбою насіння порівняно із суцільним внесенням зменшується перемішування їх з великим об'ємом ґрунту, що знижує непродуктивні витрати поживних речовин, підвищує їх концентрацію в доступній для цукрових буряків зоні та забезпечує живлення рослин протягом всього періоду вегетації. Це сприяє рівномірному розвитку рослин і підвищенню рівномірності розмірно-масових характеристик коренеплодів, що має важливе значення при вирощуванні цукрових буряків.

Боротьбу з бур'янами за удосконаленого способу вирощування цукрових буряків здійснюють шляхом обприскування посівів гербіцидами у фазі формування рослинами бур'янів сім'ядоль. Це дає можливість підвищити ефективність дії гербіцидів і досягти знищення бур'янів до $93 . .100 \%$ за мінімальних норм їх внесення. При цьому хімічне навантаження на довкілля знижується на $40 . .60 \%$.

Розпушування ґрунту в міжряддях до змикання листя в суміжних рядках за удосконаленого 
способу вирощування цукрових буряків здійснюють пошарово на глибину $H=10 \ldots 12 \mathrm{~cm}$ шляхом ешелонованого встановлення розпушуючих робочих органів на глибину ходу через кожні $3 . .4$ см $\left(h_{i}=3 \ldots 4\right.$ см відносно тих, що йдуть попереду) за співвідношенням $h_{i}=0,3 H$. Пошарове розпушування ґрунту в міжряддях за такою схемою розстановки робочих органів забезпечує більш ефективне його розпушування $з$ утворенням $65,3 \%$ (за масою) агротехнічно корисних часток розміром до 10 мм, або в 2,8 рази більше порівняно $з$ розпушуванням одразу на глибину $10 \ldots 12$ см. Внаслідок цього покращуються агрофрізичні умови для розвитку цукрових буряків, що має важливе значення для підвищення їх продуктивності. Пошаровий обробіток ґрунту в міжряддях при догляді за посівами цукрових буряків шляхом ешелонованого встановлення розпушуючих робочих органів на глибину ходу через кожні 3...4 см порівняно з обробітком окремими агрегатами дає можливість зменшити витрати праці на 0,66 люд.-год. /га, витрати пального - на 4,3 кг/га.

3 метою створення необхідних умов для росту і розвитку цукрових буряків, забезпечення елементами живлення рослин протягом періоду вегетації під час найбільшої їх потреби розроблено спосіб внесення мінеральних добрив [11]. Цей спосіб забезпечує внесення необхідних річних норм елементів живлення та загортання мінеральних добрив у ґрунт на оптимальну глибину при проведенні основного глибокого обробітку ґрунту, обробітку ґрунту під час сівби насіння та при підживленні рослин (рис. 2).

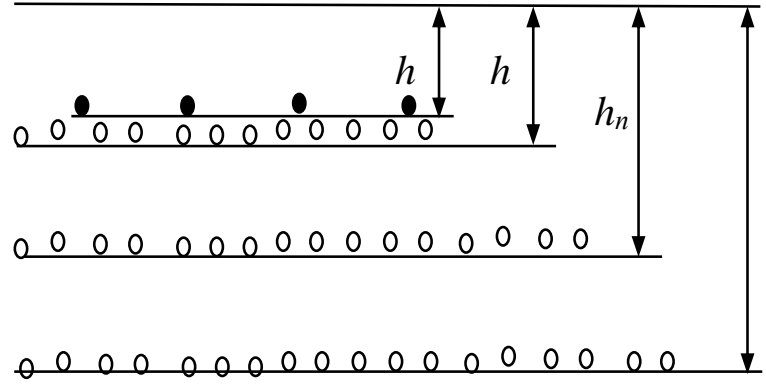

\section{Рис. 2. Схема внесення мінеральних добрив}

Згідно з результатами досліджень глибина загортання мінеральних добрив під час сівби насіння $\left(h_{c}, \mathrm{~cm}\right)$ і при підживленні рослин $\left(h_{n}, \mathrm{~cm}\right)$ визначається залежно від глибини їх загортання при проведенні основного обробітку ґрунту $\left(h_{0}=30 \ldots 32 \mathrm{~cm}\right)$ за співвідношенням

$$
h_{\Pi}=2 h_{\mathrm{c}}=(0,2 \ldots 0,5) h_{0} .
$$

Необхідні річні норми елементів живлення (Д, кг/га) розподіляються для внесення при прове- денні основного глибокого обробітку ґрунту (Д, кг/га), під час сівби насіння (Д2, кг/га) та при підживленні рослин (Дз, кг/га) за співвідношенням:

$$
\begin{gathered}
Д_{1}=(0,7 \ldots 1,0) \text { Д; } \text { Д }_{2}=(0 \ldots 0,15) \text { Д; } \\
\text { Д }_{3}=(0 \ldots 0,25) \text { Д }
\end{gathered}
$$

Так, при загортанні мінеральних добрив під час проведення основного обробітку ґрунту на глибину 30 см глибина загортання їх під час сівби насіння становить 3,0...7,5 cм, а глибина загортання мінеральних добрив під час підживлення рослин дорівнює $6,0 \ldots 15,0$ см. Це забезпечує удобрення цукрових буряків протягом всього періоду вегетації, необхідну кількість елементів живлення під час найбільшої в них потреби залежно від глибини розміщення кореневої системи.

3 метою створення необхідних умов для розвитку рослин цукрових буряків на важких за механічним складом ґрунтах та після випадання значної кількості опадів і підвищення щільності ґрунту розроблено технологічну схему агрегату та спосіб міжрядного обробітку ґрунту з підгортанням рослин у рядках [10]. Запропонований спосіб забезпечує розпушування ґрунту в зоні міжрядь за оптимального співвідношення ширини смуги розпушування, глибини його розпушування та глибини ходу підгортачів залежно від ширини міжрядь (рис. 3), що запобігає утворенню великих грудок та дає можливість зменшити пошкодження рослин.

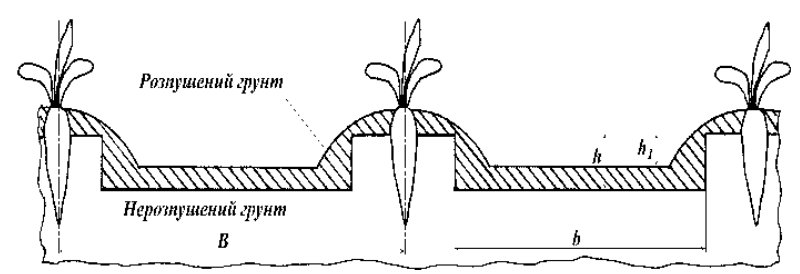

Рис. 3. Технологічна схема міжрядного обробітку ґрунту з підгортанням рослин цукрових буряків у рядках

Згідно з результатами досліджень обробіток ґрунту в зоні міжрядь потрібно проводити без розпушування і зсування його в захисних зонах рядків, з наступним підгортанням із зони міжрядь та укладанням розпушеного дрібно-грудкуватого ґрунту поверх нерозпушеного в захисній зоні рядка у валок, висота якого встановлюється залежно від розвитку та розмірних характеристик рослин. 3гідно з результатами досліджень необхідні глибина $(h, c M)$ і ширина $(b, c M)$ зони розпушування ґрунту в міжряддях визначаються залежно від ширини міжрядь $(b, c m)$ за співвідношенням

$$
h=0,4 b=\frac{4}{15} B .
$$

Глибина ходу підгортачів $\left(h_{1}, c M\right)$ у зоні розпушеного ґрунту в міжряддях для забезпечення 
необхідної висоти підгортання рослин визначається залежно від глибини його розпушування $(h, C M)$

$$
h_{1}=(0,25 \ldots 0,50) h .
$$

Вологість ґрунту в зоні розпушеного шару збільшується порівняно із звичайним способом міжрядного обробітку на 5\% (від 14 до $19 \%$ ), знищення бур'янів у зоні рядків - на $12 \%$ (від $60 \%$ до $72 \%$ ), пошкодження коренеплодів цукрових буряків під час збирання бурякозбиральними машинами зменшується на $16 . .22 \%$.

На основі теоретичних і лабораторно-польових досліджень розроблено спосіб збирання буряків з підкопуванням коренеплодів для умов підвищеної щільності і низької вологості ґрунту та обґрунтовано параметри робочих органів коренезбиральної машини для розпушування ґрунту в зоні рядків [12]. розроблені спосіб і технічні засоби забезпечують розпушування ґрунту в зоні міжрядь на оптимальній відстані від осьової лінії рядка (від коренеплодів) та на оптимальну глибину (рис. 9).

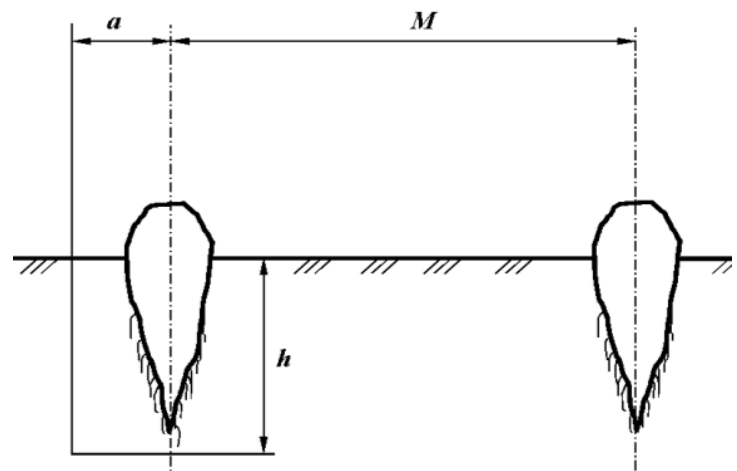

Рис. 4. Спосіб збирання буряків з підкопуванням коренеплодів

За результатами досліджень відстань від осьової лінії рядка до лінії руху підкопувальної лапи в міжрядді (a, cм) для забезпечення руйнування зв'язків коренеплодів з ґрунтом без їх пошкодження визначається залежно від ширини міжрядь (М, см) із виразу

$$
a=(0,20 \ldots 0,24) \mathrm{M} \text {. }
$$

Глибина ходу підкопувальної лапи (глибина підкопування) в зоні рядка ( $h, \quad$ см) для забезпечення мінімальної глибини підкопування коренеплодів без обрізання хвостової частини визначається залежно від ширини міжрядь (М, см) за фрормулою

$$
h=0,2 M+14 \mathrm{~cm} \text {. }
$$

Так, за ширини міжрядь 30 см і 45 см відстань від осьової лінії рядка до лінії руху підкопувальної лапи в міжрядді, за якої можливе надійне руйнування зв'язків коренеплодів 3 ґрунтом без їх пошкодження, повинна становити залежно від діаметра коренеплодів відповідно $6,0 \ldots 7,2 \mathrm{~cm}$ і 9,0...10,8 см, а глибина ходу підкопувальної лапи (глибина підкопування) в зоні рядка повинна становити відповідно 20 см і 23 см для забезпечення мінімальної глибини підкопування коренеплодів без обрізання їх хвостової частини.

Застосування розробленого способу дає можливість в умовах підвищеної щільності і низької вологості ґрунту забезпечити якісне збирання коренеплодів цукрових буряків. Показники якості виконання технологічного процесу збирання (табл. 1) відповідають вимогам діючого Національного стандарту України (ДСТУ).

Таблиця 1 Показники якості збирання коренеплодів

\begin{tabular}{|l|c|}
\hline \multicolumn{1}{|c|}{ Назва показників } & $\begin{array}{c}\text { Значення } \\
\text { показників }\end{array}$ \\
\hline Втрати коренеплодів (за масою), \% & 1,2 \\
\hline Загальна забрудненість вороху & \\
коренеплодів, \% & 6,8 \\
у тому числі рослинними рештками, \% & 2,4 \\
\hline $\begin{array}{l}\text { Кількість механічно пошкоджених } \\
\text { коренеплодів, \% }\end{array}$ & 4,8 \\
\hline
\end{tabular}

Розроблені теоретичні основи викопування коренеплодів цукрових буряків за підвищеної щільності та недостатньої вологості ґрунту дають можливість оптимізовувати параметри викопувальних робочих органів бурякозбиральних машин залежно від стану ґрунту, зменшити втрати коренеплодів до 1,2...2,0 \%, пошкодження - до 5,0 \%.

Висновок. В результаті проведення наукових досліджень удосконалено технологічні процеси вирощування та збирання цукрових буряків і розроблено конструктивні схеми, вихідні вимоги для машин, здатних забезпечити ведення буряківництва у сучасному конкурентному ринковому середовищі. А застосування бурякозбирального комбайна з оптимально обґрунтованими викопувальними робочими органами дасть можливість значно знизити втрати і пошкодження коренеплодів.

\section{Література:}

1. Академік Василенко Петро Мефодійович корифей землеробської механіки в Україні: монографрія / С.М. Ніколаєнко, В.М. Булгаков, Д.Г. Войтюк, В.В. Адамчук, Л.М. Тіщенко; за ред. С.М. Ніколаєнка. - К.: Аграрна наука, 2015. - 264 с.

2. Василенко П. М. Теория движения частицы по шероховатым поверхностям сельскохозяйственных машин [Текст] / П. М. Василенко. - К.: УАСХН, 1960. - 289 с.

3. Василенко П. М. Автоматизация процессов сельскохозяйственного производства / П. М. Василенко, И. И. Василенко. - М.: Колос, 1964. - 384 с. 
4. Василенко П. М. Методика построения расчетных моделей функционирования механических систем (машин и машинных агрегатов): Учебное пособие / П. М. Василенко, В. П. Василенко. - К.: Полиграфика, 1980. - 135 с.

5. Василенко П. М. Введение в земледельческую механику / П. М. Василенко. - К.: Сільгоспосвіта. 1996. - 252 с.

6. Довідник з механізації виробництва цукрових буряків / О. О. Проценко, В. І. Паламарчук, А. М. Козачук та ін.; за ред. О. О. Проценко. - К.: Урожай, 1987. - 250 с.

7. Зуєв Н. М. Застосування технічних засобів на збиранні цукрових буряків / Зуєв Н. М., Курило В. Л., Гументик М. Я. // Цукрові буряки. - 2000. №4 (16). - С.8 - 9 .

8. Науково-методичні рекомендації щодо збирання цукрових буряків / М. В. Роїк, М. М. Зуєв, В. Л. Курило, М. Я. Гументик. - К.: Аграрна наука, 2002. - 40 с.

9. Патент №46333А, Україна, А01C7/00, A01D91/02. Спосіб вирощування цукрових буряків /О. О.Іващенко, М. М.Зуєв, В. Л.Курило, А. С.Заришняк; Опубл. 15.05.2002, Бюл. №5.

10. Патент №23581, Україна, А01B79/00. Спосіб міжрядного обробітку ґрунту/ В. Л. Курило, В. В. Чуйко, І. А. Пачевський, О. Б. Хіврич; Опубл. 25.05.2007, Бюл. №7.

11. Патент №28553, Україна, А01С3/00, А01C21/00. Спосіб внесення мінеральних добрив/ В. Л. Курило; Опубл. 10.12.2007, Бюл. №20.

13. Патент №38527, Україна, A01D51/00. Спосіб збирання цукрових буряків/ В. Л. Курило, І. А. Пачевський, А. В. Курило; Опубл. 12.01.2009, Бюл. №1.

14. Пришляк В. М. Особливості механізації землеробства на схилових землях і методологічні аспекти щодо їх дослідження // Вісник Харківського державного технічного університету сільського господарства, Випуск 21 - Механізація сільськогосподарського виробництва. - Харків: ХДТУСГ, 2003 - С. $276-281$.

15. Сінченко В. М. Управління формуванням продуктивності цукрових буряків: монографія. Київ: ІБКіЦБ НААН України, 2012. 582 с.

\section{References}

1. Nikolaunko, S. M., Bulgakov, V. M., Voityuk, D. G., Adamchuk, V. V., Tishchenko, L. M. (2015) Akademik Vasilenko Petro Mefodiyovich - luminary of agricultural mechanics in Ukraine. - Kyiv: Ahrarna nauka. - $264 \mathrm{p}$.

2. Vasilenko, P. M. (1960) Theory of particle motion on rough surfaces of agricultural machines. Kyiv: UASKhN. -289 p.

3. Vasilenko, P. M., Vasilenko, I. I. (1960) Automation of agricultural production processes. M .: Kolos, 1964. - 384 p.

4. Vasilenko, P. M., Vasilenko, V. P. (1980) Methods of construction of calculation models of functioning of mechanical systems (machines and machine units): Textbook. - Kyiv: Printing. -320 p.

5. Vasilenko, P. M. (1996) Introduction to agricultural mechanics. Kyiv: Silgosposvita. - 252 p.

6. Protsenko, O. O., Palamarchuk V. I, Kozachuk, A. M. and others (1987) Handbook of mechanization of sugar beet production; for order $\mathrm{O}$. O. Protsenko. - Kyiv: Urozhay. - 250 p.

7. Zuev, N. M, Kurilo, V. L., Gumenik, M. Ya. (2000) The use of technical means for harvesting sugar beets, Sugar beets. (4 (16)), pp. 8-9.

8. Roik, M. V., Zuev, M. M., Курило, V. L., Gumentic, M. Я. (2002) Scientific and methodological recommendations for harvesting sugar beets. Kyiv: Ahrarna nauka. - 40 p.

9. Patent №46333A, Uk, 2002.

10. Patent №46333, Uk, 2007.

11. Patent №46333, Uk, 2007.

12. Patent №38527, Uk, 2009.

13. Pryshlyak, V. M. (2003) Peculiarities of mechanization of agriculture on sloping lands and methodological aspects of their research, Bulletin of the Kharkiv State Technical University of Agriculture, Issue 21 - Mechanization of agricultural production. - Kharkiv: KhDTU of A. - pp. 276-281.

14. Sinchenko, V. M. (2012). Management of formation of productivity of sugar beets. Kyiv: I of BC and SB of the NA of AS of Ukraine. - 582 p.

\section{Аннотация}

\section{Оптимизация параметров рабочих органов машин для выращивания и уборки сахарной свеклы}

\section{В.Л. Курило, В.М. Пришляк}

В статье изложены усовершенствованные агротехнические мероприятия выращивания и уборки сахарной свеклы, обеспечивающие повышение качества предпосевной обработки почвы, посева семян, эффективность использования минеральных удобрений и гербицидов, что обеспечивает создание более благоприятных агрофизических условий для роста и развития растений, повышения урожайности сахарной свеклы и уменьшения затрат на производство.

Представлено разработанные технологические процессы и оптимизированные параметры рабочих органов машин для возделывания и уборки сахарной свеклы. Сюда относится проведение локального 
внесения минеральных удобрений, предпосевная обработка почвы и посев семян за один проход одним комбинированным агрегатом, борьба с сорняками путем опрыскивания посевов гербицидами в фазе формирования растениями сорняков семядолей. Большую эффективность показало послойное рыхления почвы в междурядьях до смыкания листьев в смежных рядках. Для сахарной свеклы важно создание необходимых агрохимических условий для роста и развития растений за счет обеспечения необходимыми элементами питания в период наибольшей их потребности во время интенсивной вегетации свеклы. Также исследовано уход за растениями сахарной свеклы при повышенной плотности на тяжелых по механическому составу почвах и после выпадения значительного количества осадков, особенности междурядной обработки почвы с окучиванием растений в рядках, механизированную уборку свеклы с подкапыванием корнеплодов для условий повышенной плотности и низкой влажности почвы. Целесообразность инновационных разработок подтверждена проведенными экспериментальными исследованиями в полевых условиях.

Результаты исследований могут быть использованы для совершенствования и оптимизации зональных технологий и технических средств для выращивания и уборки сахарной свеклы, а также в учебном процессе при подготовке будущих агроинженеры к инновационной проектной деятельности.

Ключевые слова: оптимизация, параметры, рабочие органы, машина, выращивания, уборка, сахарная свекла.

\title{
Abstract
}

\section{Optimization of parameters of working bodies of machines for growing and harvesting sugar beets}

\author{
V.L. Kurylo, V.M. Pryshliak
}

The article outlines improved agrotechnical measures for the cultivation and harvesting of sugar beets, which ensure an increase in the quality of pre-sowing soil cultivation, sowing of seeds, the efficiency of the use of mineral fertilizers and herbicides, which ensures the creation of more favorable agrophysical conditions for the growth and development of plants, increasing the yield of sugar beets and reducing the cost of production.

The developed technological processes and optimized parameters of the working bodies of machines for the cultivation and harvesting of sugar beet are presented. This includes local application of mineral fertilizers, presowing soil cultivation and sowing seeds in one pass with one combined unit, weed control by spraying crops with herbicides in the phase of the formation of cotyledon weeds by plants. The layer-by-layer loosening of the soil in the aisles to the closure of leaves in adjacent rows showed great efficiency. For sugar beet, it is important to create the necessary agrochemical conditions for the growth and development of plants by providing the necessary nutrients during the period of their greatest need during the intensive vegetation of beets. Also the peculiarities of sugar beet production at increased density on heavy-textured soils and after a significant amount of precipitation were studied. The features of inter-row soil cultivation with hilling plants in rows, mechanized harvesting of beets with digging in root crops for conditions of increased density and low soil moisture were determined. The feasibility of innovative developments has been confirmed by experimental studies in the field.

The research results can be used to improve and optimize zonal technologies and technical means for growing and harvesting sugar beets, as well as in the educational process in preparing future agricultural engineers for innovative project activities.

Keywords: optimization, parameters, working bodies, machine, cultivation, harvesting, sugar beets.

Бібліографічне посилання/ Bibliography citation: Harvard

Kurylo, V. L. and Pryshliak, V. M. (2020) 'Optimization of parameters of working bodies of machines for growing and harvesting sugar beets', Engineering of nature management, (3(17), pp. 70 - 75.

Подано до редакції / Received: 08.09.2020

ISSN 2311-1828

http://enm.khntusg.com.ua
Інженерія природокористування, 2020, №3(17), с. 70 - 75

Engineering of nature management, 2020, \#3(17), p. 70 - 75 